\title{
Adenine causes cell cycle arrest and autophagy of chronic myelogenous leukemia K562 cells via AMP-activated protein kinase signaling
}

\author{
SAN-YUAN CHEN ${ }^{1}$, CHUN-HSIANG LIN ${ }^{2}$, JIUN-TSAI LIN ${ }^{3}$, YI-FANG CHENG ${ }^{4}$, \\ HAN-MIN CHEN $^{3,5}$ and SHAO-HSUAN KAO ${ }^{2,6}$
}

\begin{abstract}
${ }^{1}$ Department of Traditional Chinese Medicine, Ditmanson Medical Foundation Chia-Yi Christian Hospital, Chiayi 600; ${ }^{2}$ Institute of Biochemistry, Microbiology and Immunology, Chung Shan Medical University, Taichung 402; ${ }^{3}$ Institute of Applied Science and Engineering, Catholic Fu Jen University, New Taipei 242; ${ }^{4}$ Energenesis Biomedical Co. Ltd., New Taipei 235; ${ }^{5}$ Department of Life Science, Catholic Fu Jen University, New Taipei $242 ;{ }^{6}$ Clinical Laboratory, Chung Shan Medical University Hospital, Taichung 402, Taiwan R.O.C.
\end{abstract}

Received December 3, 2015; Accepted May 11, 2017

DOI: $10.3892 / 01.2017 .6890$

\begin{abstract}
AMP-activated protein kinase (AMPK) is known as a pivotal regulator of cellular metabolism. Mounting evidences have demonstrated that AMPK activation exerts tumor suppressive activity on leukemia cells. The present study reported that adenine, an AMPK activator, triggers cell cycle arrest and autophagy of human chronic myelogenous leukemia K562 cells consequently suppressing cell viability. The present findings revealed that adenine treatment $(4.0-8.0 \mathrm{mM})$ significantly inhibited the viability of K562 cells to $69.3 \pm 2.5 \%$ ( $24 \mathrm{~h}$ ) and $53.4 \pm 2.1 \%$ (48 h) of the control. Flow cytometric analysis revealed that there was a significant accumulation in $G_{2} / M$ phase, but not sub- $G_{1}$ phase K562 cells following exposure to adenine. Additional investigation demonstrated that adenine treatments significantly increased the number of acidic vesicular organelles and the level of autophagosomal microtubule associated protein 1 light chain $3 \alpha$ (LC3) marker. By contrast, cleavage of caspase-9, caspase- 3 and poly-ADPribose polymerase was insignificantly affected in K562 cells following adenine treatment. In K562 cells, adenine was able to markedly promote the phosphorylation of AMPK $\alpha$ and suppress the phosphorylation of mammalian target of rapamycin (mTOR), a downstream target of AMPK. In addition, inhibiting AMPK phosphorylation using dorsomorphin restored mTOR phosphorylation, inhibited the accumulation of LC3 and significantly recovered the suppressed cell viability
\end{abstract}

Correspondence to: Dr Shao-Hsuan Kao, Institute of Biochemistry, Microbiology and Immunology, Chung Shan Medical University, 110, Section 1 Jianguo North Road, Taichung 402, Taiwan R.O.C. E-mail:kaosh@csmu.edu.tw

Key words: adenine, AMP-activated protein kinase, autophagy, cell cycle arrest, chronic myelogenous leukaemia K562 cells in response to adenine. Taken together, the present results demonstrated that adenine induced $\mathrm{G}_{2} / \mathrm{M}$ phase arrest and autophagic cell death, consequently suppressing the viability of K562 cells, which may attribute to the AMPK activation triggered by adenine. These findings provide evidence that adenine may be beneficial to chronic myelogenous leukemia therapy by suppressing excessive cell proliferation.

\section{Introduction}

Chronic myelogenous leukemia (CML) is a chronic myeloproliferative disorder, which causes uncontrolled growth of immature myeloid cells (1). The BCR RhoGEF and GTPase activating protein (BCR)-ABL proto-oncogene 1 nonreceptor tyrosine kinase $(A B L)$ gene rearrangement is the main characteristic of $\mathrm{CML}$, which expresses the oncogenic fusion protein BCR-ABL (2). BCR-ABL is a constitutively active tyrosine kinase, which activates multiple signaling pathways and consequently promotes malignant transformation, including uncontrolled cell proliferation (3), abnormal cell adhesion (4), and resistance to typical apoptotic inducer anti-leukemic drugs $(5,6)$. Thus, formation of the BCR-ABL fusion gene serves an essential role in the pathogenesis of CML (7). Previously, imatinib, a specific ABL kinase inhibitor, was established as the standard treatment for CML (8).

In addition to targeting BCR-ABL kinase, previous studies have revealed that several pathways are important for CML cell survival, which may be potential targets for developing novel anti-leukemia drugs $(9,10)$. Among these pathways, AMP-activated protein kinase (AMPK) signaling has been reported to possess anti-leukemia activity (11). AMPK serves an important role in energy metabolism in response to changes in cellular fuel levels (12). Furthermore, mounting evidences have suggested that AMPK could be a target for tumor prevention and treatment (7). Previous studies have revealed that AMPK activators exhibit anti-leukemia effects in CML cells by triggering apoptosis and autophagy $(3,4)$. Thus, the 
identification and characterization of AMPK activators is important, and beneficial for the development of potential anti-leukemia drugs.

The present study aimed to investigate whether adenine, a purine compound that induces AMPK activation, exhibits anti-leukemia effects on human CML cells. Furthermore, the underlying mechanism, with emphasis on AMPK signaling was evaluated. The results revealed that adenine suppressed cell viability of K562 cells and induced accumulation of G0/G1 phase cells. In parallel, it was observed that adenine triggered K562 cells autophagy. Finally, it was demonstrated that suppressed cell viability, accumulation of $\mathrm{G}_{0} / \mathrm{G}_{1}$ phase cells and induction of autophagy were associated with AMPK activation in response to adenine.

\section{Materials and methods}

Reagents. All chemicals were obtained from Sigma-Aldrich (Merck KGaA, Darmstadt, Germany) unless otherwise specified. RPMI-1640 medium and fetal bovine serum (FBS) were purchased from Invitrogen (Thermo Fisher Scientific, Inc., Waltham, MA, USA). Antibodies against $\beta$-actin, caspase-3, caspase-8, phosphorylated (p)-AMPK (T172; cat. no. 2535), AMPK (cat. no. 2532), poly-ADP-ribose polymerase (PARP) (cat. no. 9532), cell division cycle (Cdc)25 (cat. no. 3652), cyclin-dependent kinase (CDK)2 (cat. no. 2546), CDK4 (cat. no. 12790), CDK6 (cat. no. 13331), cyclin B (cat. no. 4135), cyclin E (cat. no. 20808), Weel-like protein kinase (Wee1) (cat. no. 13084), autophagy protein (Atg)5 (cat. no. 12994), beclin-1 (cat. no. 3495) and microtubule associated protein 1 light chain $3 \alpha$ (LC3) (cat. no. 3868) were purchased from Cell Signaling Technologies, Inc. (Danvers, MA, USA). Anti-human glyceraldehyde 3-phosphate dehydrogenase (GAPDH) (cat. no. ab9485), horseradish peroxidase-conjugated anti-mouse IgG (cat. no. ab6789) and anti-rabbit IgG (cat. no. ab6721) antibodies were purchased from Abcam (Cambridge, UK).

Cell culture and experimental treatments. The human CML K562 cell line (CCL-243 ${ }^{\mathrm{TM}}$ ) was obtained from the American Type Culture Collection (Manassas, VA, USA) and maintained in RPMI-1640 medium supplemented with $10 \% \mathrm{FBS}$ at $37^{\circ} \mathrm{C}$ in a humidified atmosphere with $5 \% \mathrm{CO}_{2}$. Cells at the density of $5 \times 10^{5}$ cells $/ \mathrm{ml}$ were collected and were passaged twice prior to being subcultured T-75 flasks (Corning Incorporated, Corning, NY, USA) for subsequent treatments.

For treatments, cells were seeded in 6-well plates at an initial density of $1 \times 10^{5}$ cells $/ \mathrm{ml}$ and grown to $\sim 80 \%$ confluence at $37^{\circ} \mathrm{C}$. Treatments were performed by incubating cells with various concentrations of adenine $(0.5,1.0,2.0,4.0$ or $8.0 \mathrm{mM}$ ) in serum-free RPMI-1640 for $16 \mathrm{~h}$. AMPK inhibition was performed by pretreating cells with $5 \mu \mathrm{M}$ dorsomorphin (cat. no. P5499; Sigma-Aldrich; Merck KGaA) for $2 \mathrm{~h}$, and then incubating the pretreated cells with $4.0 \mathrm{mM}$ adenine for $24 \mathrm{~h}$ or $48 \mathrm{~h}$. Following treatment, the cells were washed with PBS (25 mM sodium phosphate, $150 \mathrm{mM} \mathrm{NaCl}, \mathrm{pH}$ 7.2) and collected for subsequent analyses.

Cell viability assay. Cell viability was assessed using an MTT assay protocol as previously described (13) in the absence or presence of adenine. After 24 or $48 \mathrm{~h}$ treatments, cells were

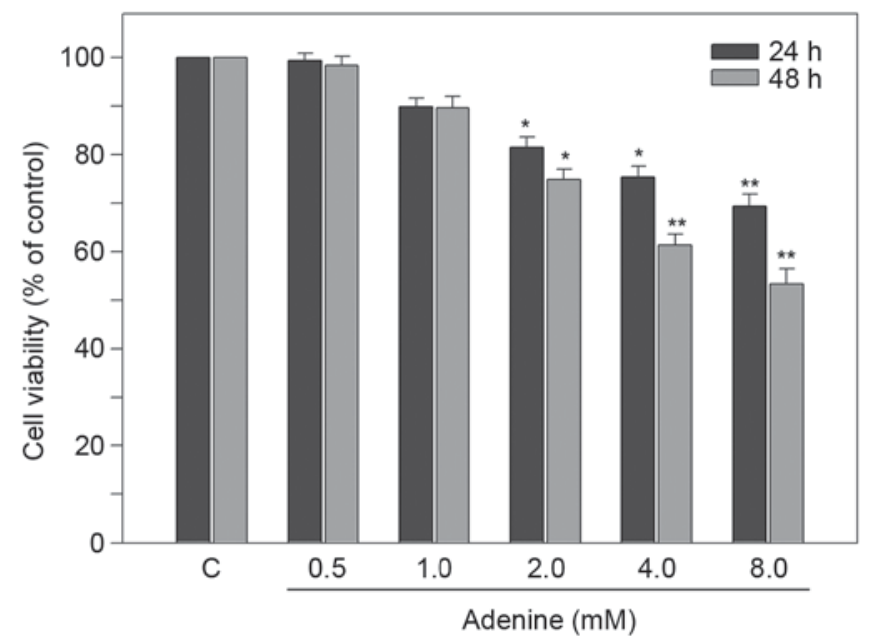

Figure 1. Adenine suppresses the viability of K562 cells. Cells were treated with various concentrations of adenine $(0.5,1.0,2.0,4.0$ or $8.0 \mathrm{mM})$ for 24 or $48 \mathrm{~h}$, and then subjected to a cell viability assay. Data are expressed as the mean \pm standard error of the mean following three independent experiments. ${ }^{*} \mathrm{P}<0.05$ and ${ }^{* *} \mathrm{P}<0.01$ as compared with the untreated control. $\mathrm{C}$, control.

harvested, and then incubated with MTT $(0.5 \mathrm{mg} / \mathrm{ml})$ at $37^{\circ} \mathrm{C}$ for $4 \mathrm{~h}$. The cell viability was directly proportional to the production of formazan, which was dissolved in isopropanol and determined by measuring the absorbance at $570 \mathrm{~nm}$ using a microplate reader (SpectraMAX 360 pc; Molecular Devices, LCC, Sunnyvale, CA, USA).

Cell cycle distribution analysis. Cells were starved for $16 \mathrm{~h}$ in serum-free medium, and then cultured in fresh serumcontaining medium at $37^{\circ} \mathrm{C}$ for $24 \mathrm{~h}$ to allow cell-cycle progression. Following different treatments, cells were fixed and analyzed by flow cytometry to determine cell cycle distribution. At the end of each treatment, cells were collected, fixed with $1 \mathrm{ml}$ of ice-cold $70 \%$ ethanol on ice for $30 \mathrm{~min}$, incubated at $-20^{\circ} \mathrm{C}$ for $24 \mathrm{~h}$ and centrifuged at $380 \mathrm{xg}$ at $4^{\circ} \mathrm{C}$ for $5 \mathrm{~min}$. Cell pellets were reacted with $1 \mathrm{ml}$ cold staining solution containing $20 \mu \mathrm{g} / \mathrm{ml}$ propidium iodide, $20 \mu \mathrm{g} / \mathrm{ml}$ RNase A and $1 \%$ Triton $\mathrm{X}-100$, incubated at $4^{\circ} \mathrm{C}$ for $15 \mathrm{~min}$ in the dark, and then analyzed using a FACS Calibur system with CellQuest ${ }^{\mathrm{TM}}$ software (version 2.0) (both BD Biosciences, Franklin Lakes, NJ, USA). Representative results were acquired from three independent experiments.

Western blot analysis. Cells were washed with PBS and then incubated with lysis buffer (50 mM Tris- $\mathrm{HCl}, \mathrm{pH} 7.5,1 \%$ Nonidet P-40, $1 \mathrm{mM}$ phenylmethylsulfonyl fluoride and $1 \mathrm{mM}$ $\mathrm{NaF}$ ) containing complete protease inhibitor cocktail (Roche Applied Science, Mannheim, Germany) for $1 \mathrm{~h}$ at $4^{\circ} \mathrm{C}$. The resulting supernatants were collected for protein Bquantitation using a bicinchoninic acid kit (Pierce; Thermo Fisher Scientific, Inc.). Crude proteins $(20 \mu \mathrm{g})$ were subjected to $12.5 \%$ SDS-PAGE, transferred to a nitrocellulose membrane (EMD Millipore, Billerica, MA, USA) and then incubated with $5 \% \mathrm{w} / \mathrm{v}$ skimmed milk/PBS at room temperature for $1 \mathrm{~h}$ to block nonspecific binding. The blocked membrane was then incubated with primary antibodies (1:1,000 dilution) at $25^{\circ} \mathrm{C}$ for $2 \mathrm{~h}$, followed by incubation with peroxidase-conjugated 

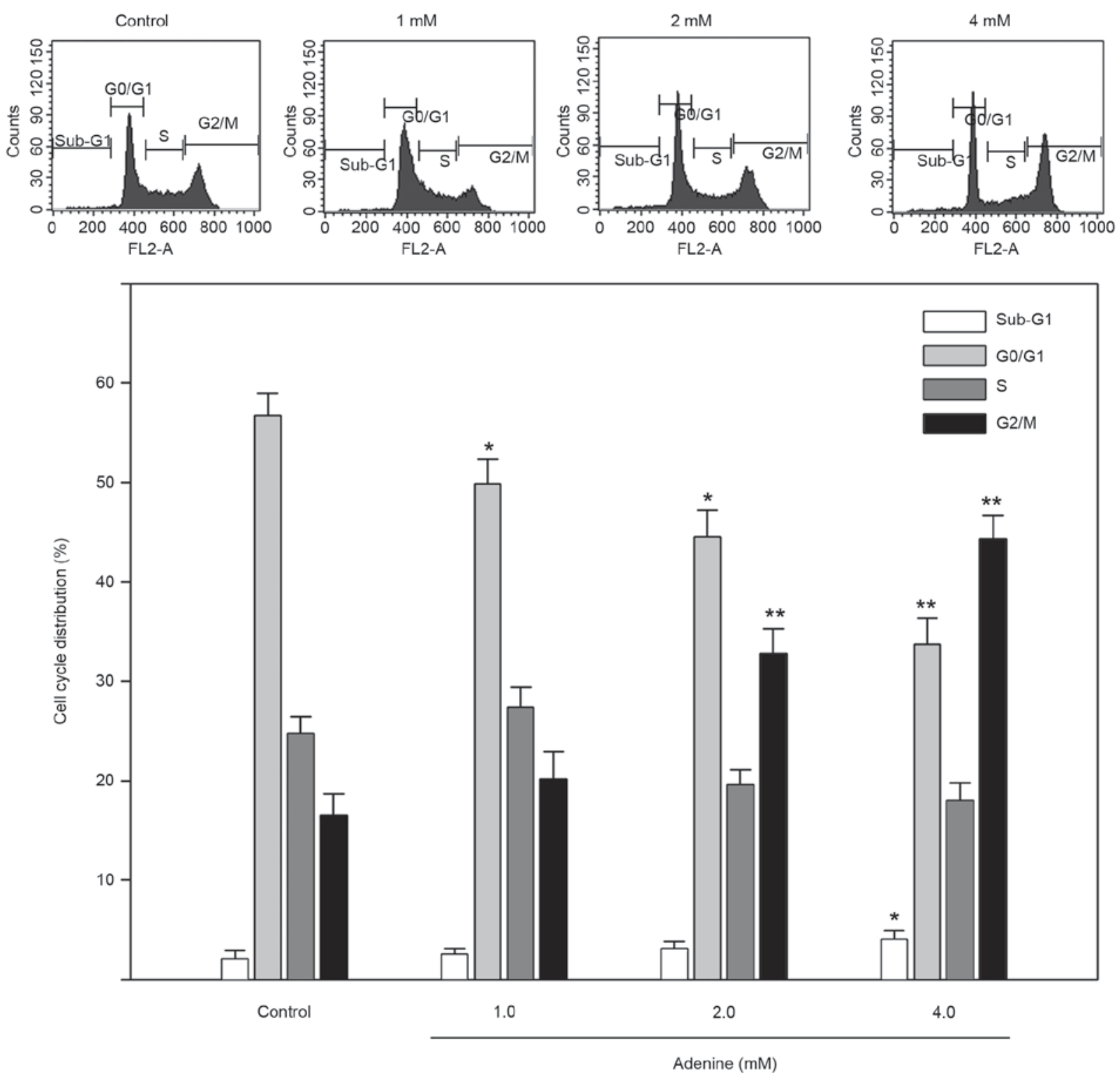

Figure 2. Effects of adenine on the cell cycle distribution of K562 cells. Cells were treated with 1.0,2.0 or $4.0 \mathrm{mM}$ adenine for $24 \mathrm{~h}$, and then subjected to flow cytometric analysis for determining cell cycle phases. The ratio of each phase is presented as a percentage. Data are expressed as the mean \pm standard error of the mean following three independent experiments. ${ }^{*} \mathrm{P}<0.05$ and ${ }^{* *} \mathrm{P}<0.01$ as compared with the untreated control.

anti-IgG secondary antibodies $\left(1: 2,000\right.$ dilution) at $25^{\circ} \mathrm{C}$ for $1 \mathrm{~h}$. Detailed information for antibodies were described in the reagents. The blocked membrane without incubation with primary antibodies was also incubated with secondary antibodies for specificity test, and a nonsignificant signal was detected as the control. Signal development was performed using an enhanced chemiluminescence reagent (EMD Millipore). Luminescent signals were acquired and quantified using an image analysis system (LAS-4000 with Image Reader LAS-4000 version 2.1, Fuji, Tokyo, Japan). GAPDH was used as an internal control.

Quantification of acidic vesicular organelles (AVOs) using acridine orange staining and flow cytometric analysis. Cells $\left(1 \times 10^{4}\right)$ were incubated with acridine orange at $25^{\circ} \mathrm{C}$ for $17 \mathrm{~min}$, harvested with trypsin-EDTA, and then collected in phenol red-free growth medium (Thermo Fisher Scientific, Inc.). Green $(510-530 \mathrm{~nm})$ and red $(650 \mathrm{~nm})$ fluorescence emission from cells illuminated with blue $(488 \mathrm{~nm})$ excitation light was analyzed using FACS Calibur system using CellQuest software as mentioned above. With acridine orange staining, bright green and faint red fluorescence was observed in the cytoplasm and nucleolus, respectively, and bright red fluorescence was observed in acidic compartments $(2,14)$. Since the intensity of the red fluorescence is proportional to the degree of acidity, the volume of the cellular acidic compartment could be quantified (15).

Statistical analysis. Data are expressed as the mean \pm standard error of the mean following three independent experiments. Statistical analysis was performed by using SigmaStat (version 4.0, Systat Software, Inc, San Jose, CA, USA). Statistical significance analysis was determined using one-way analysis of variance followed by Dunnett's test for multiple comparisons with the control. $\mathrm{P}<0.05$ was considered to indicate a statistically significant difference. 

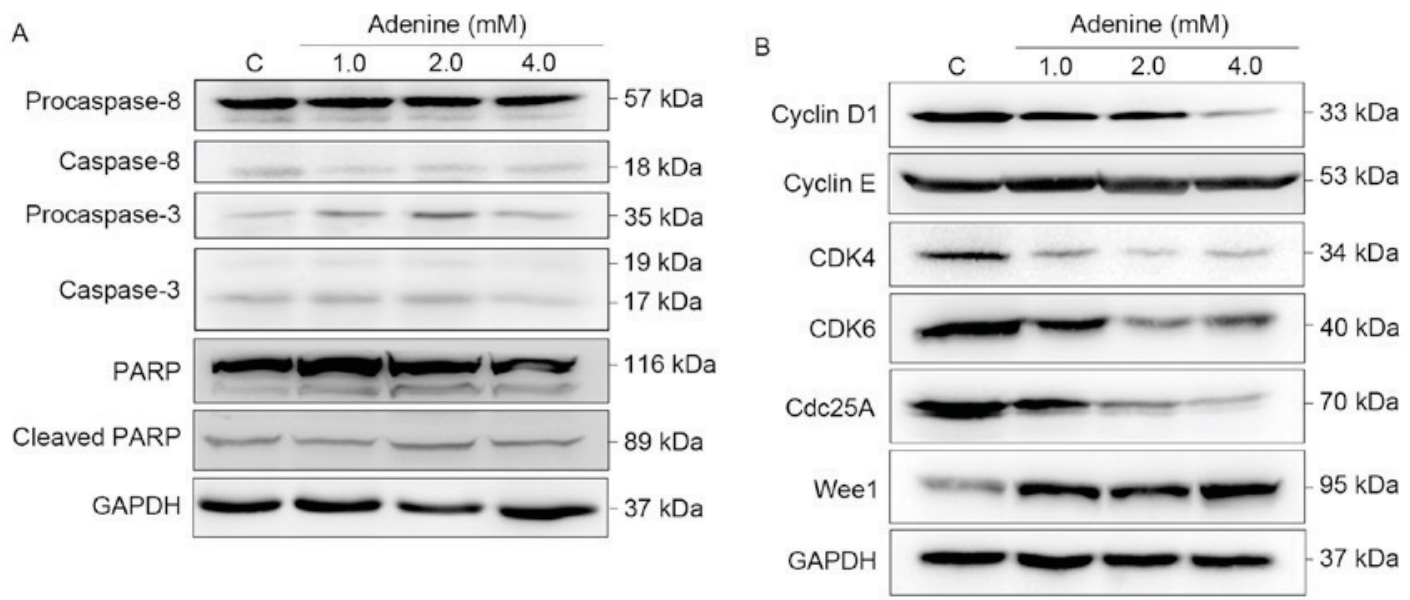

Figure 3. Adenine inhibits cell cycle regulators but not caspase effectors. Cells were treated with 1.0, 2.0 and $4.0 \mathrm{mM}$ adenine for $24 \mathrm{~h}$, and then lysed for determination of protein expression levels using western blot analysis. GAPDH was used as an internal control. The apparent molecular weights of the detected proteins are indicated. PARP, poly-ADP-ribose polymerase; CDK, cyclin-dependent kinase; Cdc25A, cell division cycle 25A; Wee1, Wee1-like protein kinase; C, control.
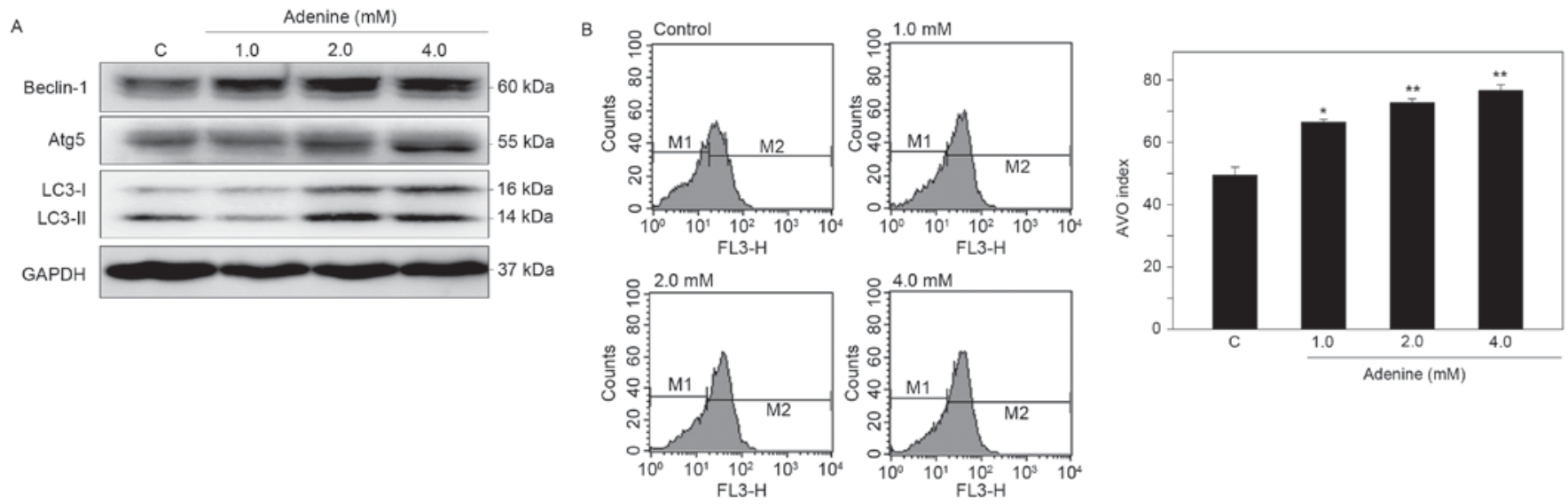

Figure 4. Adenine induces autophagy in K562 cells. Cells were treated with 1.0, 2.0 or $4.0 \mathrm{mM}$ adenine for $24 \mathrm{~h}$, and then subjected to (A) western blot analysis for determination of protein levels, or (B) acridine orange staining for detection of AVOs. GAPDH was used as internal control. The apparent molecular weights of the detected proteins are indicated. Quantitative data are expressed as the mean \pm standard error of the mean following three independent experiments. ${ }^{*} \mathrm{P}<0.05$ and ${ }^{* *} \mathrm{P}<0.01$ as compared with the untreated control. AVO, acidic vesicular organelle; Atg5, autophagy protein 5; LC3, microtubule associated protein 1 light chain $3 \alpha$; C, control.

\section{Results}

Adenine suppresses the viability of human CML K562 cells. To investigate the effect of adenine on human CML K562 cells, cell viability was determined using MTT assay. As presented in Fig. 1, for $24 \mathrm{~h}$ treatments, the viability of K562 cells was significantly reduced to $81.5 \pm 2.1,75.4 \pm 2.2$ and $69.3 \pm 2.5 \%$ of the control in response to 2, 4 and $8 \mathrm{mM}$ adenine, respectively (all $\mathrm{P}<0.05)$. For $48 \mathrm{~h}$ treatments, the cell viability was further reduced to $61.3 \pm 2.3$ and $53.4 \pm 3.1 \%$ of the control in response to 4 and $8 \mathrm{mM}$ adenine, respectively (both $\mathrm{P}<0.01$ ). These findings revealed that adenine at concentrations of 2, 4 and $8 \mathrm{mM}$ significantly inhibited the viability of K562 cells.

Adenine induces $G_{2} / M$ cell cycle arrest and alters cell cycle regulators in human CML K562 cells. To explore the inhibited cell viability in response to adenine, the cell cycle distribution of K562 cells treated with adenine was determined using flow cytometric analysis. As presented in Fig. 2, the sub- $\mathrm{G}_{1}$ phase ratio was increased by $4.1 \pm 0.7 \%$ in $\mathrm{K} 562$ cells treated with $4 \mathrm{mM}$ adenine compared with the control group $(P<0.05)$. In addition, the $\mathrm{G}_{2} / \mathrm{M}$ phase ratio was significantly increased in K562 cells treated with $2 \mathrm{mM}(32.1 \pm 2.7 \%)$ and $4 \mathrm{mM}(43.8 \pm 2.1 \%)$ adenine compared with that in the untreated control group (both $P<0.01$ ). The $\mathrm{G}_{0} / \mathrm{G}_{1}$ phase ratio was significantly decreased in K562 cells treated with $2 \mathrm{mM}$ $(44.6 \pm 2.7 \%)$ and $4 \mathrm{mM}(33.8 \pm 2.4 \%)$ adenine compared with that in untreated cells (both $\mathrm{P}<0.05$ ).

Since cell viability and cell cycle distribution were altered following adenine treatment, the effects of adenine on caspase signaling cascades, and cell cycle regulators were then investigated. As presented in Fig. 3A, cleavage of caspase-8, caspase-3 and PARP was insignificantly affected by adenine treatments $(1.0,2.0$ or $4.0 \mathrm{mM})$. Regarding cell cycle regulators, the protein expression levels of Cyclin D1, CDK4, CDK6 and $\mathrm{Cdc} 25 \mathrm{~A}$ were markedly decreased in response to adenine treatments (Fig. 3B). By contrast, the level of Weel was elevated upon adenine stimulation. Notably, Cyclin E protein expression 

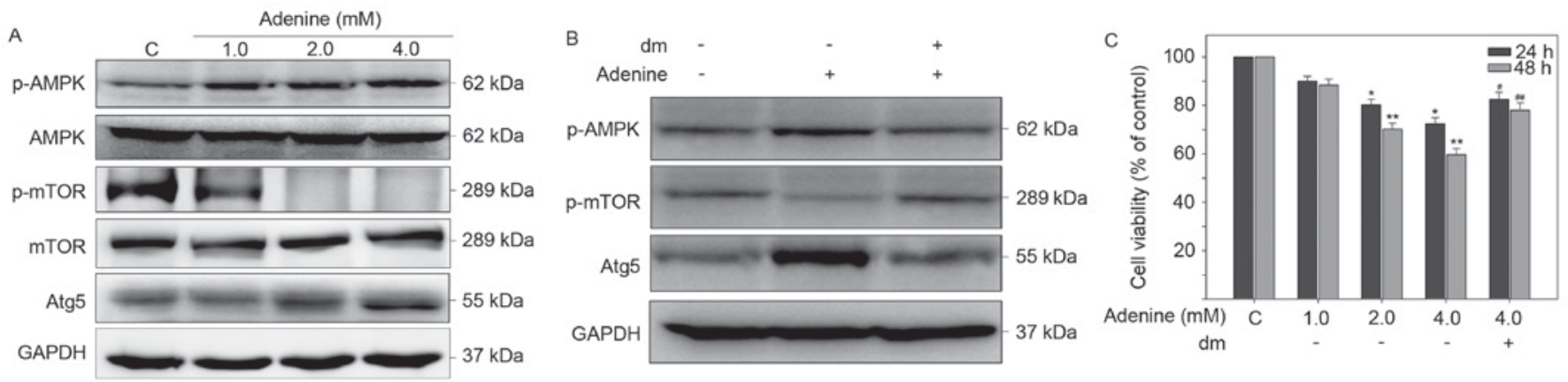

Figure 5. AMPK activation is involved in autophagy and suppression of viability of K562 cells in response to adenine. Cells were (A) treated with adenine alone or (B) pretreated with AMPK inhibitor dm $(5 \mu \mathrm{M})$ for $2 \mathrm{~h}$ followed by treatment with adenine for $24 \mathrm{~h}$, and then subjected to western blot analysis. GAPDH was used as internal control. The apparent molecular weights of the detected proteins are indicated. Quantitative data are expressed as the mean \pm standard error of the mean following three independent experiments. (C) A cell viability assay was performed to investigate the effects of dm on K564 cells. "P $<0.05$ and ${ }^{* *} \mathrm{P}<0.01$ as compared with the untreated control; ${ }^{*} \mathrm{P}<0.05$ and ${ }^{\# \#} \mathrm{P}<0.01$ as compared with the $4.0 \mathrm{mM}$ adenine treatment group. AMPK, AMP-activated protein kinase; p, phosphorylated; mTOR, mechanistic target of rapamycin; Atg5, autophagy protein 5; dm, dorsomorphin; C, control.

was insignificantly affected by adenine. Taken together, these findings suggest that adenine treatment induces $\mathrm{G}_{2} / \mathrm{M}$ cell cycle arrest without involvement of the activation of caspase signaling cascades and consequent apoptosis of K562 cells.

Adenine induces autophagy of human CML K562 cells. To determine whether adenine suppresses cell viability via autophagic cell death, induction of autophagy in K562 cells was then examined. Western blot analysis demonstrated that adenine markedly upregulated the protein expression of Beclin-1 and Atg5, and promoted the conversion of LC3-I to LC3-II in the cells (Fig. 4A). In addition, using acridine orange staining and flow cytometric quantification, adenine was identified to significantly increase the number of AVOs in K562 cells in a dose-dependent manner (Fig. 4B). These findings suggest that adenine treatment promotes the formation of autophagosomes in K562 cells.

Adenine induces the phosphorylation of AMPKa, contributing to inhibition of mTOR and autophagic signaling cascades in $K 562$ cells. Adenine has been reported to exert antitumoral activity on human renal carcinoma 786-O cells via AMPK activation (16). Thus, the roles of AMPK signaling in autophagic cell death of K562 cells in response to adenine were investigated. As presented in Fig. 5A, adenine markedly enhance the phosphorylation of AMPK $\alpha$ at T172, reduced the phosphorylation of mTOR at S2448 and elevated the protein expression level of autophagic marker Atg 5 compared with untreated cells. By contrast, pretreatment with the AMPK inhibitor dorsomorphin $(\mathrm{dm})$ reversed the expression changes to p-AMPKa, p-mTOR and Atg5 in K562 cells following exposure to adenine (Fig. 5B). In addition, pretreatment with dm significantly restored the viability of K562 cells suppressed by $4.0 \mathrm{mM}$ adenine (Fig. 5C). Collectively, these findings suggest that the AMPK/mTOR signaling pathway is involved in adenine-induced autophagy and consequent viability inhibition of K562 cells.

\section{Discussion}

Clinically, the Philadelphia chromosome exists in $\sim 95 \%$ of adults with CML and expresses the BCR-ABL fusion protein with uncontrolled tyrosine kinase activity, resulting in abnormal regulation of downstream signaling pathways (17). The aberrant activation of signaling pathways, including the RAS/mitogen activated protein kinase kinase/extracellular signal-related kinase and phosphoinositide 3-kinase/RAC-alpha serine/threonine-protein kinase pathways, may promote cell proliferation, diminish cell apoptosis or contribute to growth factor independence of cancer cells $(18,19)$. Therefore, tyrosine kinase inhibitors targeting the BCR-ABL fusion protein, including imatinib, dasatinib and nilotinib, are used for CML treatment, and have demonstrated improved outcomes in patients with CML (20). However, high relapse rates, drug resistance and high mortality rates associated with transplantation remain challenges for CML treatment (21).

Previous studies have revealed that AMPK activators can suppress several types of tumors, including pancreatic, bladder and prostate cancer, through AMPK-dependent apoptosis (19-21). In addition, AMPK has been reported as a potential target that regulates various signaling pathways, subsequently exhibiting antileukemia activity (22). Among the signaling pathways regulated by AMPK, mTOR is known to perform a central role in antitumor activity (23). Recently, several compounds, including metformin and myrtucommulone $\mathrm{A}$, have been reported to exert antileukemia activity via activation of the AMPK/mTOR signaling pathway $(24,25)$. Similarly, the present results revealed that adenine suppressed the viability of K562 cells through activation of the AMPK/mTOR signaling pathway, resulting in $\mathrm{G}_{2} / \mathrm{M}$ phase arrest and autophagic cell death.

Autophagy serves an important role in regulating cellular physiology, removing senescent organelles and degrading long-lived proteins $(26,27)$. In starved cells, the fatty acids and amino acids produced by hydrolysis of lipids, and proteins in autophagolysosomes provide energy to maintain cell survival (28). However, elongated autophagy is proposed to trigger autophagic caspase-independent type II programmed cell death (29). Thus, the roles of autophagy in sustaining or killing cancer cells are complicated. Although cytotoxicity of antitumor drugs is diminished by autophagy to a certain extent (30), reduced expression of autophagic genes, including Atg4, Atg5 and Atg7, has been 
reported to promote tumor formation in genetically-engineered mice $(31,32)$. Collectively, the findings suggest that autophagy possesses tumor suppressive activity. In the present study, it was demonstrated that adenine can trigger autophagic cell death, but not apoptosis, consequently suppressing the viability of K562 cells. Thus the results of the current study indicate that adenine may serve as a potential anti-leukemia agent.

In conclusion, the present study demonstrated that adenine treatment significantly suppresses the viability of CML K562 cells through activation of the AMPK/mTOR pathway and synergistic induction of $\mathrm{G}_{2} / \mathrm{M}$ phase arrest, and autophagy signaling. Thus, adenine represents a promising effective antiproliferative agent against human leukemia cells.

\section{References}

1. Clarkson B, Strife A, Wisniewski D, Lambek CL and Liu C: Chronic myelogenous leukemia as a paradigm of early cancer and possible curative strategies. Leukemia 17: 1211-1262, 2003.

2. Traganos F and Darzynkiewicz Z: Lysosomal proton pump activity: Supravital cell staining with acridine orange differentiates leukocyte subpopulations. Methods Cell Biol 41: 185-194, 1994.

3. Vakana E, Altman JK, Glaser H, Donato NJ and Platanias LC: Antileukemic effects of AMPK activators on BCR-ABLexpressing cells. Blood 118: 6399-6402, 2011.

4. Sujobert P, Poulain L, Paubelle E, Zylbersztejn F, Grenier A, Lambert M, Townsend EC, Brusq JM, Nicodeme E, Decrooqc J, et al: Co-activation of AMPK and mTORC1 induces cytotoxicity in acute myeloid leukemia. Cell Rep 11: 1446-1457, 2015.

5. Bedi A, Zehnbauer BA, Barber JP, Sharkis SJ and Jones RJ: Inhibition of apoptosis by BCR-ABL in chronic myeloid leukemia. Blood 83: 2038-2044, 1994

6. Klionsky DJ, Meijer AJ and Codogno P: Autophagy and p70S6 kinase. Autophagy 1: 59-61, 2005.

7. Kim I and He YY: Targeting the AMP-activated protein kinase for cancer prevention and therapy. Front Oncol 3: 175, 2013.

8. Vakana E and Platanias LC: AMPK in BCR-ABL expressing leukemias. Regulatory effects and therapeutic implications. Oncotarget 2: 1322-1328, 2011.

9. Druker B, Okuda K, Matulonis U, Salgia R, Roberts T and Griffin JD: Tyrosine phosphorylation of rasGAP and associated proteins in chronic myelogenous leukemia cell lines. Blood 79: 2215-2220, 1992.

10. Gotoh A, Miyazawa K, Ohyashiki K, Tauchi T, Boswell HS, Broxmeyer HE and Toyama K: Tyrosine phosphorylation and activation of focal adhesion kinase (p125FAK) by BCR-ABL oncoprotein. Exp Hematol 23: 1153-1159, 1995.

11. Fernandes A, Azevedo MM, Pereira O, Sampaio-Marques B, Paiva A, Correia-Neves M, Castro I and Ludovico P: Proteolytic systems and AMP-activated protein kinase are critical targets of acute myeloid leukemia therapeutic approaches. Oncotarget 6 : 31428-31440, 2015.

12. Long YC and Zierath JR: AMP-activated protein kinase signaling in metabolic regulation. J Clin Invest 116: 1776-1783, 2006.

13. Denizot F and Lang R: Rapid colorimetric assay for cell growth and survival. Modifications to the tetrazolium dye procedure giving improved sensitivity and reliability. J Immunol Methods 89: 271-277, 1986

14. Stankiewicz M, Jonas W, Hadas E, Cabaj W and Douch PG: Supravital staining of eosinophils. Int J Parasitol 26: 445-446, 1996.
15. Paglin S, Hollister T, Delohery T, Hackett N, McMahill M, Sphicas E, Domingo D and Yahalom J: A novel response of cancer cells to radiation involves autophagy and formation of acidic vesicles. Cancer Res 61: 439-444, 2001.

16. Hsu CY, Lin CH, Lin JT, Cheng YF, Chen HM and Kao SH: Purine analogue ENERGI-F706 induces apoptosis of 786-O renal carcinoma cells via 5'-adenosine monophosphate-activated protein kinase activation. Mol Med Rep 12: 4566-4571, 2015.

17. Sattler M and Griffin JD: Molecular mechanisms of transformation by the BCR-ABL oncogene. Semin Hematol 40 (2 Suppl 2): S4-S10, 2003.

18. Skorski T, Kanakaraj P, Nieborowska-Skorska M, Ratajczak MZ, Wen SC, Zon G, Gewirtz AM, Perussia B and Calabretta B: Phosphatidylinositol-3 kinase activity is regulated by BCR/ABL and is required for the growth of Philadelphia chromosomepositive cells. Blood 86: 726-736, 1995.

19. Cortez D, Reuther G and Pendergast AM: The Bcr-Abl tyrosine kinase activates mitogenic signaling pathways and stimulates G1-to-S phase transition in hematopoietic cells. Oncogene 15: 2333-2342, 1997.

20. Mace ML, Dahl J and Jabbour EJ: Which tyrosine-kinase inhibitor to use first in chronic phase chronic myelogenous leukemia? Expert Opin Pharmacother 16: 999-1007, 2015.

21. Adekola K, Popat U and Ciurea SO: An update on allogeneic hematopoietic progenitor cell transplantation for myeloproliferative neoplasms in the era of tyrosine kinase inhibitors. Bone Marrow Transplant 49: 1352-1359, 2014.

22. Karnevi E, Said K, Andersson R and Rosendahl AH: Metforminmediated growth inhibition involves suppression of the IGF-I receptor signalling pathway in human pancreatic cancer cells. BMC Cancer 13: 235, 2013.

23. Zheng QY, Jin FS, Yao C, Zhang T, Zhang GH and Ai X: Ursolic acid-induced AMP-activated protein kinase (AMPK) activation contributes to growth inhibition and apoptosis in human bladder cancer T24 cells. Biochem Biophys Res Commun 419: 741-747, 2012.

24. Sauer H, Engel S, Milosevic N, Sharifpanah F and Wartenberg M: Activation of AMP-kinase by AICAR induces apoptosis of DU-145 prostate cancer cells through generation of reactive oxygen species and activation of c-Jun N-terminal kinase. Int J Oncol 40: 501-508, 2012

25. Borthakur G, Duvvuri S, Ruvolo V, Tripathi DN, Piya S, Burks J, Jacamo R, Kojima K, Ruvolo P, Fueyo-Margareto J, et al: MDM2 inhibitor, nutlin 3a, induces p53 dependent autophagy in acute leukemia by AMP kinase activation. PLoS One 10: e0139254, 2015.

26. Mizushima N, Levine B, Cuervo AM and Klionsky DJ: Autophagy fights disease through cellular self-digestion. Nature 451: 1069-1075, 2008.

27. Levine B and Kroemer G: Autophagy in aging, disease and death: The true identity of a cell death impostor. Cell Death Differ 16: 1-2, 2009.

28. Settembre C, Fraldi A, Medina DL and Ballabio A: Signals from the lysosome: A control centre for cellular clearance and energy metabolism. Nat Rev Mol Cell Biol 14: 283-296, 2013.

29. Gozuacik D and Kimchi A: Autophagy as a cell death and tumor suppressor mechanism. Oncogene 23: 2891-2906, 2004.

30. Aredia F and Scovassi AI: Manipulation of autophagy in cancer cells: An innovative strategy to fight drug resistance. Future Med Chem 5: 1009-1021, 2013

31. Liang XH, Jackson S, Seaman M, Brown K, Kempkes B, Hibshoosh $\mathrm{H}$ and Levine B: Induction of autophagy and inhibition of tumorigenesis by beclin 1. Nature 402: 672-676, 1999.

32. Yue Z, Jin S, Yang C, Levine AJ and Heintz N: Beclin 1, an autophagy gene essential for early embryonic development, is a haploinsufficient tumor suppressor. Proc Natl Acad Sci USA 100: 15077-15082, 2003. 